\title{
EVALUATE THE CAPABILITIES AND LIMITATIONS SUSTAINABLE RURAL DEVELOPMENT IN THE KERMANSHAH DISTRICT
}

\author{
Masood Safari AliAkbari ${ }^{1}$--- Hamdollah. Pishroo ${ }^{2}$ \\ ${ }^{\prime}$ Department of Geography, Payame Noor University, I.R. of Iran \\ ${ }^{2}$ Department of Economics, Shiraz Branch, Islamic Azad University, Shiraz, Iran
}

\begin{abstract}
The purpose of this paper is to investigate the capabilities and limitations sustainable rural development in the Kermanshah district, is. Kermanshah district is, the one of Kermanshah city in the Kermanshah Province, located in the West of Iran. Province with an area of 24,640 square kilometers, the seventeenth province of Iran, the extent of. Reviews features and capabilities of the rural Kermanshah district, in order to achieve sustainable development goals of the study is considered. To assess the capabilities and limitations of sustainable rural development, Kermanshah district, the Model " driving force ( pressure), - the status quo - Response" (PSR), with emphasis on economic factors, is employed. In order to sustain economic factors are the factors that leads to rural development in a period of sustained economic terms, and the amount of economic and social prosperity for farmers and villagers to create. In the model used, studied over 10 indicators, such as access to water resources, food security, adequate income and permanent farmer's share of manufactured exports, etc. have been studied. To calculate the index, data from the Statistical Center of Iran and the Ministry of Agriculture has been used. The results of the model used, the indicators used, show that stability, rural development, agricultural activities down to reliance has been, and continues to the present situation cannot be sustainable development for rural areas surveyed have. One of the main reasons for this instability, the increasing cost of agricultural production, on the one hand, and the low prices of the other party, which has caused the value added of this sector was low and income from agricultural activities 30 percent of total rural income ), not sustainable rural development, to be held.
\end{abstract}

Keywords: Sustainable rural development, Rural features, Model driving force, Kermanshah province, Kermanshah district, Iran.

Received: 3 April 2014/ Revised: 5 June 2014/ Accepted: 12 June 2014/ Published: 17 June 2014 


\section{INTRODUCTION}

According to the latest population census in Iran in 2006, about $31 / 5$ percent of the population, which is the equivalent of $22,227,771$ people, live in rural areas (Statistical Center of Iran, 2006). In the meantime, though, the share of rural population declined steadily over the past three decades, and urbanization spread, but according to statistics, one-third of Iran's population still live in rural areas, and these regions play a fundamental role, plays in economic and social life of the country.

Accordingly, planning for rural areas, are necessary. Many factors, having impact on rural development, which is due to the dependency of rural activities, agricultural activities, have made a significant contribution to employment and rural income, and develop a large role in rural development. According to the World Bank, 1975, Rural Development, a plan to improve the lives of more economic, social and impoverished rural communities, is defined. From the $1980 \mathrm{~s}$ onwards, rural development, social development concept, the more combined. Other theories concerning rural development has been suggested that sustainable rural development, such as it is, from the perspective of 1987 , the concept of sustainable development by the International Commission on Environment and Development (WCED, 1987), which works in the field of environment, sustainable development, in a report titled ( our Common future), it has been defined as "development that current needs without prejudicing the ability of future generations to meet their own needs, to meet "(Connelly and Smith, 1999). Thus, sustainable development is development that improves lives just this generation, but future generations will also be considered.

Organization for Economic Cooperation and Development, as well as sustainable development means integrating the goals of economic, social and environmental, to maximize human welfare, current, without damaging the ability of future generations to meet their needs, it has been defined (OECD, 2001). Accordingly, since the last two decades, the concept of rural development, the concept of sustainable development has been incorporated. Sustainable rural development by the World Bank as improving living conditions and reducing poverty in rural areas, are defined. World Bank's point of view, is that rural development is a holistic issue, on which the prosperity of rural people's lives, in terms of assets, environmental, social and productively focused (World Bank, 2005, p.12 Quoted of (Connelly and Smith, 1999). In another definition, sustainable rural development, the management and conservation of natural resources, social and economic use to the best advantage, to meet present and future needs of the rural community, has been considered.

Accordingly, many of the Commission relating to rural development, including the Europe Union Commission, entitled "Agricultural and Rural Development ", is named in [1], and much of the research universities, the research sections, as agriculture and sustainable development have created. To achieve sustainable rural development, relying on agriculture, along with other activities in rural areas, the development of sustainable agriculture, noted. Sustainable agricultural approaches can solve problems in agriculture and the long-term stability, and solve current problems, can play an important role. Sustainable agriculture is an agricultural system, 
which leads to a decline in agricultural operations. This type of agriculture, the quality of life for present and future generations, by maintaining and improving the ecological processes that are dependent on it's life, improves. According to the FAO, has developed a model of sustainable agriculture, the first, a basic food needs and production requirements of present and future generations, provide, and secondly " to create permanent jobs, adequate income and decent living conditions, for practitioners agriculture provides, $\mathrm{c}$ " in preserving and enhancing the productive capacity of natural resources, to create, Fourth ", the destruction of cultural and social aspects of rural communities, prevent, and to prevent environmental pollution. Then, so what rural development, relying on agricultural development is concerned, is the sustainability of agricultural activities, economic aspects should be further examined. Purpose of economic factors are the factors that cause agricultural activities in terms of sustainable economy, and a good income for farmers and villagers, it should. Initial studies concerning rural development, the greater the 1920s, the study of problems in rural communities, and planning for the improvement of rural settlements, and began creating public infrastructure, and these studies were in economics and regional planning which is including the studies at Columbia University, on village issues, noted in 1930. Then, with views of the Rural Development Plan in 1960, the debate about proposed solutions to rural development, and in 1987, the concept of sustainable development, sustainable rural development, was introduced in the scientific literature. Among these studies, it can be (Weingarten Peter Petrick, 2004) can be mentioned that the impact of land reform on agricultural development and rural development, as has been discussed, noting that productivity large agricultural land, most of the land of wisdom, contributed to rural development. In this study, for several countries, including Russia, have been performed. World Bank, in 2005, to examine the impact of agricultural development, rural development, has been selected countries. In this study, five countries in Africa (Burkina Faso, Ghana, Senegal, Uganda, Zambia), four countries in Asia (Bangladesh, India, Indonesia and Vietnam), and three countries in Latin America (Bolivia, Brazil, and El Salvador).

Has been studied. The results of this study indicate that, although the role of agriculture as an engine of rural development is somewhat reduced (reducing the share of agriculture in the national economy), but with the use of technology in agricultural production, from the perspective of the Green Revolution Growth rural development, due to agricultural development, has been observed. In other words, by increasing the productivity of agriculture, rural development has been achieved (World Bank, 2005, p.12 Quoted of (Connelly and Smith, 1999). Other studies, the role of subsection horticulture, rural development has been done. Wish list study regarding the production of palm and palm trees, you comprehensive information about the production and consumption of the product, provided by FAO (FAO) has been done. FAO, in this technical report, the production methods, data types, geographic location, product notes and tips for improving has raised production (Shaheed Hossain, 2009). In another study (Shaheed Hossain, 2009), in Bangladesh, to examine the impact of climatic conditions on production date has been to produce a stable product. 
Climate control, and a review of the situation, based on sustainable agriculture, the cases discussed in this study, the role of distribution channels to increase farmers' income, it is of great importance, and income stability of palm growers, it has helped. Development of related industries, the dates, and international aid agencies, especially FAO's assistance in strengthening palm industry also has been effective. In another study, the study of organic agriculture palm production, is discussed. In this study, dates of production standards, based on sustainable agriculture, taking into account environmental considerations, discussed, and strategies to promote palm restraint, based on organic farming, are presented (Naturland, 2002). Studies, particularly in the areas of rural development, also in 1991, in terms of academic research, are developed. Hedayatian (1995), in a study to evaluate the development strategies, rural development and rural Zeberkhan Neishaboor, " with emphasis on agriculture is discussed. In this study, natural and human conditions prevailing in the district, both " have been considered and systematic approach to the subject has been dealt with, and for the development of rural areas, it has been suggested that the main strategy should be based on respect for human, and more accurate and more complete utilization of natural resources, placing the axles to reduce inequality, create jobs and produce more, and using environmental capacities governing district be formed. similar research in other areas of the country, especially Subject have been made, including the study of Soleimani (1998), on rural development, agricultural villages around the city anymore Kharqan, Amani Kelarijani (2001) with the theme possibilities and constraints for rural development, with emphasis on agriculture and ranching, Lefebvre villages, mountains literate city, Ayoobi (1995), rural development, agriculture oriented (samples, plain Nimbolook Qaen ), Naderi Mahdi (2002) the subject of ecological indicators for sustainable development of agriculture, the Saleh -Abad, and other research, to providing solutions for rural development in various areas have been.

\section{METHODS AND MATERIALS}

\section{A) Criteria and Indicators}

Criteria and Indicators of UN Committee on Sustainable Development [2], in 1995, the program aims to create an index of economic, social and environmental effects on sustainable development decision-making at the national level to implement.

Framework agenda, "the driving force - the status quo - reaction ", [3], by the UN Committee on Sustainable Development, as a tool to organize information about sustainable development, and in order to complete and refine, analyze and provide indicators of sustainable Development, was developed. Indicators of Sustainable Development division, under the framework of "driving force - the existing situation - reacts " to fully comply with the guidelines of the United Nations 21 (Agenda 21) is performed.

This program indicators in four categories: economic, social, environmental, and institutional or organizational, (Institutional), each. Selected indicators of the UN Committee on Sustainable Development, under the framework of "driving force - the status quo - Response" (DSR), is given in the following table. 
Table-1. Of the UN Committee on Sustainable Development (CSD), based on the DSR Driving force (Driving Force: D) - status quo (State: S) - response (Response: R)

\begin{tabular}{|c|c|c|c|c|c|}
\hline $\mathbf{R}$ & $\mathbf{S}$ & $\mathbf{D}$ & Index & Sub-Topics & Topic \\
\hline \multicolumn{6}{|c|}{ The economic dimension of sustainable development } \\
\hline & & *⿻丷木 & Per capita GDP & \multirow{2}{*}{$\begin{array}{l}\text { Economic } \\
\text { performance }\end{array}$} & \multirow{2}{*}{$\begin{array}{l}\text { Economic } \\
\text { structure }\end{array}$} \\
\hline & & * & Investment share of GDP & & \\
\hline & * & & $\begin{array}{l}\text { The balance of trade between the goods and } \\
\text { services }\end{array}$ & Trade & \\
\hline \multirow{2}{*}{\multicolumn{2}{|c|}{ * }} & & Debt share of total gross national product & \multirow[t]{2}{*}{ Financial status } & \\
\hline & & * & $\begin{array}{l}\text { The share of total official aid received, the } \\
\text { gross national product }\end{array}$ & & \\
\hline \multirow{2}{*}{\multicolumn{2}{|c|}{$*$}} & & Intensity of raw materials & $\begin{array}{l}\text { Consumption of raw } \\
\text { materials }\end{array}$ & \multirow{9}{*}{$\begin{array}{l}\text { Production and } \\
\text { consumption } \\
\text { patterns }\end{array}$} \\
\hline & & $*$ & Per capita energy consumption Per year & \multirow[t]{3}{*}{ Consumption Energy } & \\
\hline & * & & Share of energy from renewable sources & & \\
\hline \multirow{4}{*}{\multicolumn{2}{|c|}{ * }} & & Energy intensity & & \\
\hline & & * & Municipal and industrial waste & \multirow{4}{*}{$\begin{array}{l}\text { Waste production and } \\
\text { management }\end{array}$} & \\
\hline & & * & Hazardous Wastes & & \\
\hline & & $*$ & Radioactive Wastes & & \\
\hline$*$ & & & The amount of recycling and reuse of waste & & \\
\hline & $*$ & & Arbitrary distance of travel and transport & Transport & \\
\hline \multicolumn{6}{|c|}{ The social dimension of sustainable development } \\
\hline & $*$ & & Population under poverty & \multirow[t]{3}{*}{ Poverty } & \multirow{4}{*}{$\begin{array}{l}\text { Justice } \\
\text { Equality }\end{array}$} \\
\hline & \multirow[t]{2}{*}{$*$} & & Income inequality & & \\
\hline & & * & Unemployment & & \\
\hline & $*$ & & $\begin{array}{l}\text { The average income of women compared to } \\
\text { men }\end{array}$ & $\begin{array}{l}\text { Equality of men and } \\
\text { women }\end{array}$ & \\
\hline & $*$ & & Nutritional status of children & Nutrition & \\
\hline & * & & $\begin{array}{l}\text { Merck and the mortality rate of children under } \\
5 \text { years }\end{array}$ & Mortality & $\begin{array}{l}\text { Health } \\
\text { Wellness }\end{array}$ \\
\hline & * & & Life expectancy (average life) & & \\
\hline
\end{tabular}

(1) OECD Environment Directorate, USING THE PRESSURE-STATE-RESPONSE MODEL TO DEVELOP

INDICATORS OF SUSTAINABILITY, http://www.oecd.org/env/soe/

Following Table-1.

\begin{tabular}{|c|c|c|c|c|c|}
\hline $\mathbf{R}$ & $\mathbf{S}$ & D & Index & Sub- Topics & Topic \\
\hline \multicolumn{6}{|c|}{ The social dimension of sustainable development } \\
\hline & * & & Has a population of wastewater treatment facilities & Sanitation & \multirow[t]{5}{*}{ Health } \\
\hline & * & & Access to safe water & Drinking water & \\
\hline * & & & Has a population of primary health care & \multirow[t]{3}{*}{ Health Care } & \\
\hline$*$ & & & Vaccinations children, in equal contagious diseases & & \\
\hline \multirow[t]{7}{*}{$*$} & & & Consumption rates of contraceptive pills & & \\
\hline & & * & The ratio of primary to supplementary facilities & Level of Education & \multirow[t]{2}{*}{ Education } \\
\hline & & $*$ & Rate of adult literacy & Literacy & \\
\hline & $*$ & & The per capita housing & Status of residence & Housing \\
\hline & * & & $\begin{array}{l}\text { Number of recorded crimes per hundred thousand } \\
\text { people }\end{array}$ & Crime & Security \\
\hline & & $*$ & Population growth rate & Population change & Population \\
\hline & $*$ & & Urban population and urban fringe & & \\
\hline
\end{tabular}


International Journal of Geography and Geology, 2014, 3(7): 86-100

\begin{tabular}{|c|c|c|c|}
\hline & greenhouse gas emissions & Climate change & Atmosphere \\
\hline * & Consumption of ozone damaging substances & $\begin{array}{l}\text { Reducing the thickness } \\
\text { of the ozone layer }\end{array}$ & \\
\hline * & Reduce the concentration of air pollutants in urban areas & Air Quality & \\
\hline
\end{tabular}

Following Table-1.

\begin{tabular}{|c|c|c|c|c|c|}
\hline $\mathbf{R}$ & $\mathbf{S}$ & $\mathbf{D}$ & Index & Sub- Topics & Topic \\
\hline \multicolumn{6}{|c|}{ Continue the Environmental Sustainability } \\
\hline & & $*$ & The area of arable land and permanent & \multirow[t]{2}{*}{ Agriculture } & \multirow{6}{*}{ Ground } \\
\hline & & $*$ & The use of chemical fertilizers & & \\
\hline & $*$ & & Area ratio Forest cover of the total area & \multirow[t]{2}{*}{ Forest } & \\
\hline & & $*$ & Rates of deforestation and forest harvest & & \\
\hline & * & & Affected areas of desertification & Desertification & \\
\hline & $*$ & & Coverage of population and its margin & Urbanization & \\
\hline & $*$ & & Algae concentration in coastal areas & \multirow[t]{2}{*}{ coastal areas } & \multirow{3}{*}{$\begin{array}{l}\text { Oceans and } \\
\text { coastal seas }\end{array}$} \\
\hline & & $*$ & $\begin{array}{l}\text { Percent of the total pollution in coastal } \\
\text { areas }\end{array}$ & & \\
\hline & & $*$ & Annual catches of the main species of fish & Fishery & \\
\hline & & * & $\begin{array}{l}\text { The annual reduction of surface and } \\
\text { underground water sources }\end{array}$ & $\begin{array}{l}\text { The amount of } \\
\text { available water }\end{array}$ & \multirow[t]{3}{*}{ Freshwater } \\
\hline & $*$ & & BOD in water networks & \multirow[t]{2}{*}{ Water Quality } & \\
\hline & $*$ & & Faucal coati in freshwater & & \\
\hline & $*$ & & Regions studied, in terms of ecosystem & \multirow[t]{2}{*}{ Ecosystem } & \multirow{3}{*}{$\begin{array}{l}\text { Biological } \\
\text { species }\end{array}$} \\
\hline * & & & $\begin{array}{l}\text { Percentage of protected areas, the total } \\
\text { area }\end{array}$ & & \\
\hline & $*$ & & $\begin{array}{l}\begin{array}{l}\text { Abundance of some species, especially } \\
\text { selected }\end{array} \\
\end{array}$ & Biological species & \\
\hline \multicolumn{6}{|c|}{ Institutional dimension of sustainable development } \\
\hline * & & & $\begin{array}{l}\text { National Strategy for } \\
\text { Development }\end{array}$ & $\begin{array}{l}\text { Implementation } \\
\text { Strategies }\end{array}$ & \multirow[t]{2}{*}{$\begin{array}{l}\text { Institutional } \\
\text { Framework }\end{array}$} \\
\hline * & & & $\begin{array}{l}\text { Implementation of international } \\
\text { agreements }\end{array}$ & $\begin{array}{l}\text { International } \\
\text { cooperation }\end{array}$ & \\
\hline & * & & Internet access rates per thousand people & $\begin{array}{l}\text { access } \\
\text { information }\end{array}$ & \multirow[t]{4}{*}{$\begin{array}{l}\text { Institutional } \\
\text { capacity }\end{array}$} \\
\hline & * & & telephone lines per thousand people & $\begin{array}{l}\text { Communication } \\
\text { infrastructure }\end{array}$ & \\
\hline \multirow{2}{*}{\multicolumn{2}{|c|}{ * }} & & $\begin{array}{lll}\text { research and development spending } \\
\text { portion of GDP }\end{array}$ & $\begin{array}{ll}\text { Science } & \text { and } \\
\text { technology } & \\
\end{array}$ & \\
\hline & & $*$ & $\begin{array}{l}\text { economic losses and casualties of natural } \\
\text { disasters }\end{array}$ & $\begin{array}{l}\text { Level of } \\
\text { preparedness for } \\
\text { natural disasters }\end{array}$ & \\
\hline
\end{tabular}

In this context, the index "driving force (pressure)" on human activities, processes and projects on sustainable development affect. Point. This indicator causes positive or negative changes in the status of sustainable development are. In other words, the pressure, the driving forces are the environmental impacts, they create. This framework could include, for example agriculture, steep slopes, and so on. Examples of driving forces, is the rate of population increase, which reflects the impact of population increase on Sustainable Development, or the output of 
greenhouse gases, which cause climate change Compounds the current situation, it is. In the economic sphere, openness (how much the influence of the international economy), the share of exports in GDP, and the growth of the industry depend. Indicators "reaction", expressing the policies adopted, and other reactions that, to change the status quo, is applied. These indicators measure the degree of satisfaction and effectiveness of a community's response to the imposition of hands. In other words, the reaction represents the effect of reducing activity, which acts as a lever, to reduce or eliminate the effects are created and used. Organization for Economic Cooperation and Development (OECD), in 2002, to publish a series of environmental indicators for sustainable agriculture, which has received (Statistical Center of Iran, 2008). In this series of indicators include:

$1-7$ of agricultural resource - water quality

2 - Farm Management 8 - Protect the Earth

3 - Use of organic food 9 - Emissions of greenhouse gases

4 - Use of pesticides pests 10 - Biodiversity

5 - The use of water resources 11 - Wild Settlement

6 - 12 Soil quality - agricultural landscape

Table-2. Classification of environmental indicators for sustainable agriculture

\begin{tabular}{|c|c|}
\hline Sub Index & Index \\
\hline $\begin{array}{l}\text { Farmers' incomes, expenditures, farmers, farming- } \\
\text { related expenses, expenses related to agricultural } \\
\text { research }\end{array}$ & $\begin{array}{l}\text { Agricultural financing (Farm Financial } \\
\text { Resources) }\end{array}$ \\
\hline $\begin{array}{l}\text { Farm management unit (whole), Agriculture } \\
\text { organic, great food and nutritional needs of farm } \\
\text { management, pest management, non-chemical pest } \\
\text { control methods, the use of integrated management, } \\
\text { land management and soil }\end{array}$ & Farm Management (Farm Management) \\
\hline Material feeding farm & $\begin{array}{l}\text { The use of organic materials (Nutrient } \\
\text { Use) }\end{array}$ \\
\hline Indicators of risk posed by pesticides, herbicides & $\begin{array}{l}\text { The use of herbicides pesticides (Pesticide } \\
\text { Use and Risks) }\end{array}$ \\
\hline $\begin{array}{l}\text { Water use efficiency, water pressure, water resource } \\
\text { pricing }\end{array}$ & Water use (Water Use) \\
\hline $\begin{array}{l}\text { Beliefs and fertility, water, soil erosion risk by water } \\
\text { resources, the risk of erosion by wind, soil } \\
\text { contamination, }\end{array}$ & Quality soils (Soil Quality) \\
\hline $\begin{array}{lll}\text { Nitrogen balance, Nitrogen } & \text { efficiency, water } \\
\text { pollution by nitrate test } & & \\
\end{array}$ & Water Quality (Water Quality) \\
\hline Water-holding capacity & Land Protection (Land Conservation) \\
\hline $\begin{array}{l}\begin{array}{l}\text { Greenhouse gas emissions, air pollution and } \\
\text { emissions }\end{array} \\
\end{array}$ & GHG (Greenhouse gases) \\
\hline Biodiversity, ecosystem diversity & Biological Diversity (Biodiversity) \\
\hline Agricultural settlement created and its variants & Wild Habitats (Wildlife Habitat) \\
\hline $\begin{array}{l}\text { Landscape architecture, users, management, cost - } \\
\text { benefit perspective }\end{array}$ & Landscape (Landscape) \\
\hline
\end{tabular}

Other indicators, to assess agricultural sustainability is presented, some of these indicators are: 
1 -Soil erosion: include lost productivity, soil organic matter and nutrient loss through soil, water holding capacity and so on.

2 - Loss of soil organic matter (carbon and nitrogen)

3 - Soil

4 - in acidic soil (Soil Acidification)

Total of the above and other indicators to measure environmental sustainability (Gray, 1991). In sustainable agriculture, three of water, soil, use of pesticides, herbicides than other factors, emphasis is placed on the use of land in sustainable agriculture should be managed properly to increase the fertility of the land. Management of crops as well, including some that should be done with proper principles. In the latest research, as well as the role of soils and land capability in sustainable agriculture, much emphasis has been. Legislation necessary for the proper use of the soil, and appropriate methods to prevent soil erosion, such as items that should be on sustainable agriculture, should be considered. Food security as well, the important things that must be considered (Eric and Navarrete, 2009). Also, to convert the principal agriculture, sustainable agriculture, which has been proposed as a "return to sustainable agriculture," as is. These principles guide the use of pesticides, including herbicides, fertilizers, and more. The purpose of this principle is to achieve organic farming. In general, the economic dimensions of sustainable agricultural development in the field of micro-and macro-economic issues, can be studied. Microeconomic issues, to assess the sustainability issues of agricultural wisdom, Deals and profitability will exploitation activities, the contribution of each of the factors of production, profitability by product, review, and macroeconomic issues, mostly working in agriculture, in The whole economic system is analyzed. One of the most important indicators of sustainability in agriculture, discussion profitability or profitability (Profitability), agricultural activity, or in other words, creating a permanent and adequate incomes for farmers. Agricultural activities, income can be generated by multiplying the price of each unit, acquired, and the cost can be divided into fixed costs (unrelated to production) and variable costs, can be divided. International Institute for Sustainable Development (IISD), also in 1995, in one of its investigations, to provide economic indicators of sustainable agriculture, is discussed. For stability, have physical and economic sustainability index, is calculated. To calculate the economic sustainability of agriculture, the agricultural sector from two perspectives, the following should be evaluated:

1 - the producer's perspective: economic sustainability of agricultural activities, should be able to net a return on sales of agricultural commodities, to create. In other words, a producer, a producer surplus or economic rent (the efficiency of production factors used in production), in a period of time, exist.

2 - view of the consumer: the consumer, the two issues are important. First, food quality, and the excess consumption in a period of time. The consumer, in terms of the constant use of sustainability, in a defined time period.

The World Bank, in their studies, sustainable consumption, as one of the most important indicators of economic sustainability of the agricultural sector, emphasis has. In other words, agricultural economic perspective, when it is stable, the farmer an annual consumption over a one 
year period, does not change. This means that the farmers assets such as natural resources, manpower, and all his financial assets during the period, not to decline. The cost of resources used in agriculture, should be calculated. Water production factors, the most important economic assets that, in developing countries, faced with large losses. The government also subsidized the agricultural sector must be calculated and entered in the analysis of the stability.

\section{B) In the study area}

Kermanshah province, Kurdistan province to the north, the south, the provinces of Lorestan and Ilam province in the East and the West to Iraq, is limited. The center of Kermanshah Province, the Kermanshah city. According to statistics in 2011, Kermanshah province, 14 district, 31 cities, 31 zone and 86 villages have been formed in this city, in terms of being in a vast and fertile plains Mahidasht, And along the river of Gharesoo, located in a specific geographical location, its high-yield farmland, it adds extra importance.

Map No-1. Geographic location of Kermanshah, Iran

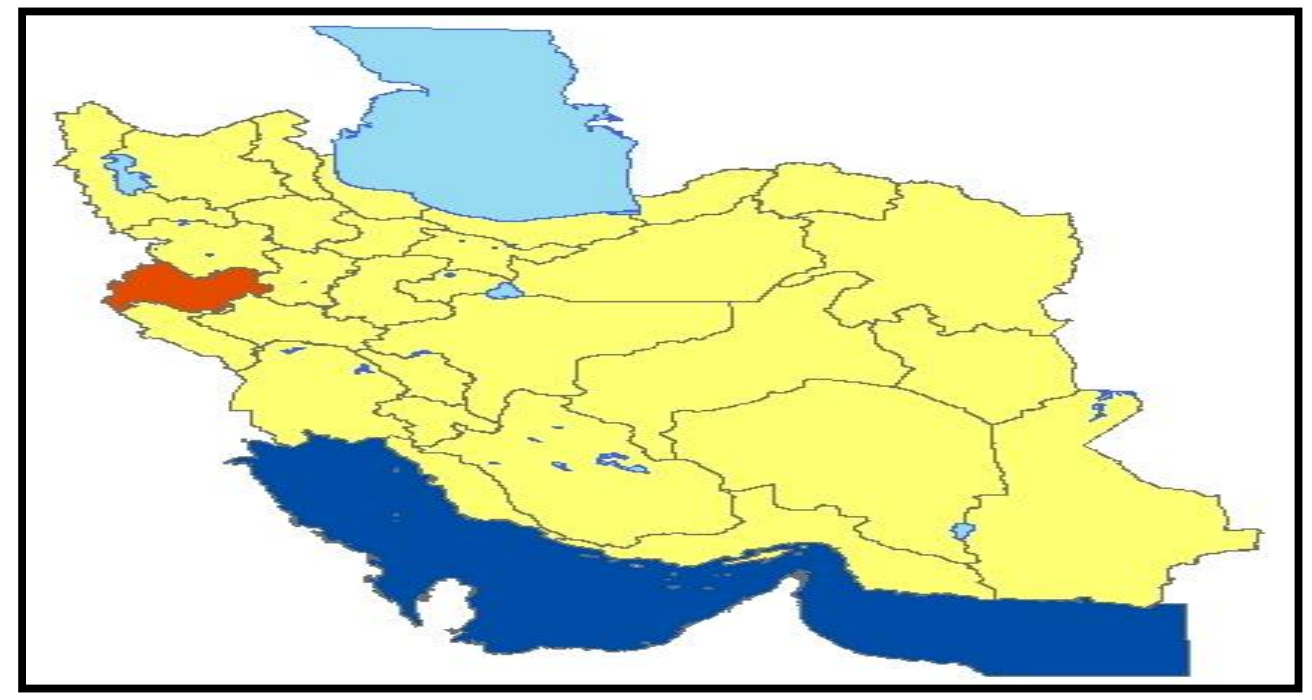

Kermanshah, in terms of climate, with four seasons at a time, for example, Qasr-e Shirin, a warm climate, and the falcon, and the DA, in cold weather, and Kermanshah, West of Islamabad temperate climates are. Total rainfall of the province, an average of $500 \mathrm{~mm}$ per year, the annual loss of 12 billion cubic meters of atmosphere in there, and agricultural production in the province has already reached 4 million tons. Than 18 million hectares of arable land, 900 hectares of shares province, and $1 / 5$ hectares of gardens, the total area of the province, more than $2 / 4$ million ha are recommended. Agricultural production to 4 million tons, two thirds of millions of tons of crops, horticulture 300 thousand tons, 300 thousand tons of livestock, and value of its products to reach 1000 billion USD per year. With approximately 33,265 hectares of gardens available, the cropping pattern gardens (water and fruit dry) of 24 products there, including 33 percent of Walnut, 18 percent grapes, $10 \%$ apple, and $8 \%$ olive or $6 \%$ of the pomegranate, and the rest to 
other fruit trees formed shows. proportion of non fruit dry plantations (pine and eucalyptus), $10 / 93$ per cent. Most of the gardens in the city DA, sort of $22 \%$, the $18 \%, 14 \%$, is located in Islamabad.

Map No-2. Position in the Kermanshah district in Kermanshah province

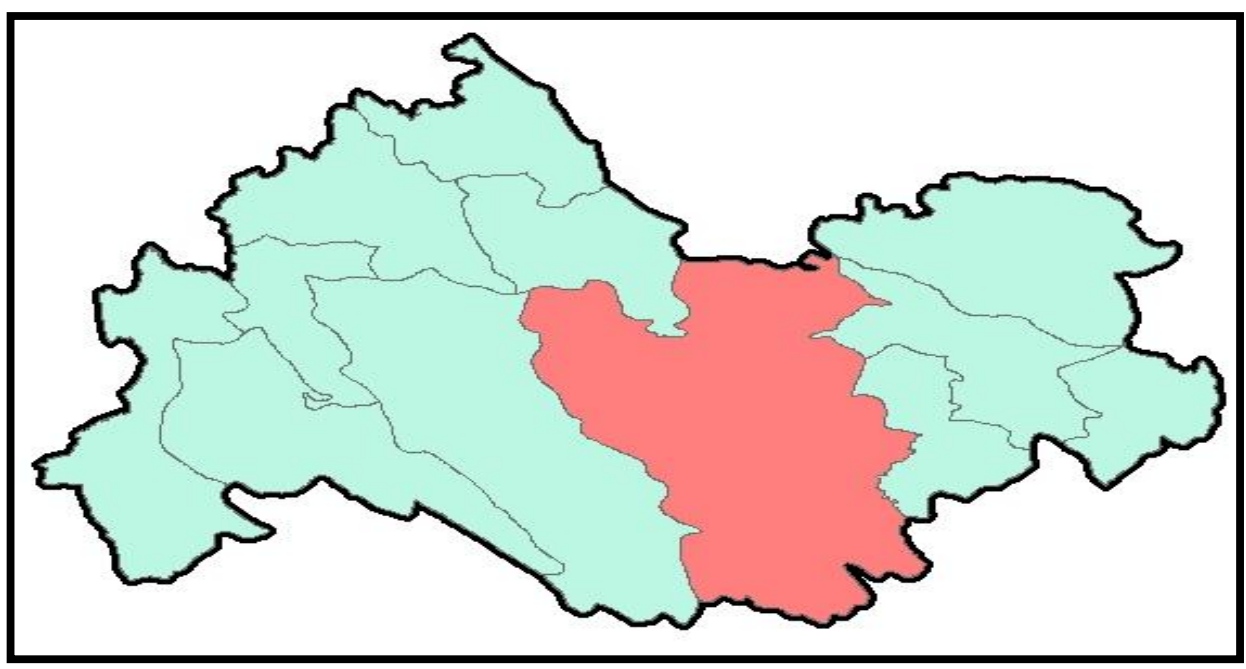

\section{C) Data Collection}

The data used in this study is collected from several sources. Data needed to calculate the food security of the data generated Ministry of Agriculture, in the years 2011-2002, and the data used to calculate earnings, and the annual cost of the rural households, the Statistical Yearbook (Statistical Center of Iran, 2008), and to collect data on agricultural exports, the customs statistics released in Iran, as well as for calculating other indicators of agricultural A statistics Iran by the Ministry of Agriculture, published annually, has been used.

\section{THE MODEL RESULTS}

Indicators is intended to demonstrate the sustainability of rural development through agricultural activities, should have the following characteristics (Statistical Center of Iran, 2008):

- The picture of economic pressure on rural development area, or actions taken, to show rural development.

- Indicators should be easily interpreted, and its data can, when placed in a series.

- Should be comparable with indicators and data to be international.

- Information used for the index, through the census, or the International Data obtained and are validated.

To identify appropriate indicators to assess sustainable rural development, with emphasis on the role of agriculture, the economic factors involved in the development of agriculture, should be determined. However, given the dominance of agricultural activities in the area, as the main 
activity of the villagers, any change in the economic situation, the activities have a large impact on rural income, and regional development will be.

Table-3. Factors affecting the economic, agricultural activities, and sustainable rural development, on the DSR

\begin{tabular}{|c|c|c|}
\hline Response (Response: $\mathbf{R}$ ) & Current status (State: $\mathbf{S}$ ) & $\begin{array}{l}\text { Driving force or pressure on the } \\
\text { sustainability (Driving Force: } D \text { ) }\end{array}$ \\
\hline Mass production & Agricultural production & Nutrient Requirements \\
\hline Subsidizing production inputs & Costs of agricultural production & Rising prices of production inputs \\
\hline Modification of production processes & Amount of waste products & The waste crops \\
\hline Agricultural Insurance & Damages to farmers & $\begin{array}{l}\text { Natural events such as droughts and } \\
\text { floods }\end{array}$ \\
\hline $\begin{array}{l}\text { Proportion of land under mechanized } \\
\text { irrigation (drip under pressure), the } \\
\text { total available land }\end{array}$ & Per capita water consumption & $\begin{array}{l}\text { Increased use of water on farms and } \\
\text { gardens }\end{array}$ \\
\hline $\begin{array}{l}\text { The amount of export awards to } \\
\text { exporters }\end{array}$ & Volume of agricultural exports & Low prices for agricultural export \\
\hline $\begin{array}{l}\text { Reduce your cost of production } \\
\text { agriculture }\end{array}$ & Investment rate of return & $\begin{array}{l}\text { The low rate of return on investment } \\
\text { activity }\end{array}$ \\
\hline $\begin{array}{l}\text { Switching industries and processed } \\
\text { products, the whole product }\end{array}$ & $\begin{array}{l}\text { Than unprocessed product, the } \\
\text { total output }\end{array}$ & Low value-added products \\
\hline Award for Export Award & $\begin{array}{l}\text { Agricultural exports to total } \\
\text { production }\end{array}$ & $\begin{array}{l}\text { Insufficient foreign } \text { demand } \\
\text { agricultural products }\end{array}$ \\
\hline $\begin{array}{l}\text { - Mechanization in various stages } \\
\text { - The share of overall spending on } \\
\text { agriculture }\end{array}$ & 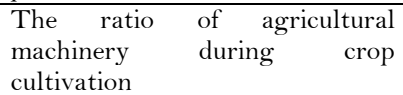 & $\begin{array}{l}\text { Traditional activities, the planting and } \\
\text { harvesting }\end{array}$ \\
\hline $\begin{array}{l}\text { - Increasing Price Guaranteed Shopping } \\
\text { - Government subsidies }\end{array}$ & $\begin{array}{l}\text { Proportion of the total } \\
\text { agricultural income of rural } \\
\text { income }\end{array}$ & $\begin{array}{l}\text { Low farm income, income volatility } \\
\text { Palm owners }\end{array}$ \\
\hline Land Consolidation & $\begin{array}{l}\text { Agricultural land per capita } \\
\text { utilization }\end{array}$ & Small agricultural land \\
\hline Increase production efficiency & Yield per hectare & Low yield per hectare \\
\hline $\begin{array}{l}\text { Reduce costs, or increase the annual } \\
\text { income }\end{array}$ & The annual cost of family & $\begin{array}{l}\text { Stability of commodity consumption } \\
\text { expenditure (annual household income) }\end{array}$ \\
\hline
\end{tabular}

Source: Results from survey

As shown in Table (3), consideration may be a factor in the economic stability of agriculture and rural development are involved, their deployment requires access to accurate and reliable data, and time series data. Accordingly, appropriate indicators to measure the economic stability of agriculture, has been selected. Table (4), the selected indicators for assessing sustainable rural development Kermanshah district, shows.

Table-4. Selected indicators for assessment of sustainable rural development Kermanshah district

\begin{tabular}{|c|c|c|c|c|}
\hline $\begin{array}{l}\text { Symbol } \\
\text { index }\end{array}$ & Threats & Reactions & Index & Row \\
\hline Index 1 & $\begin{array}{l}\text { Rate of increase in the cost of } \\
\text { agricultural production }\end{array}$ & $\begin{array}{l}\text { Increased rates of } \\
\text { product price }\end{array}$ & Profitability Index & 1 \\
\hline Imdex 2 & $\begin{array}{l}\text { Rate of increase in the cost of } \\
\text { agricultural production }\end{array}$ & $\begin{array}{l}\text { Increased rates } \\
\text { guaranteed purchase }\end{array}$ & $\begin{array}{ll}\text { Index } & \text { supportive } \\
\text { government policies }\end{array}$ & 2 \\
\hline Index 3 & $\begin{array}{l}\text { Rate of annual household costs } \\
\text { increase }\end{array}$ & $\begin{array}{l}\text { Rate increase annual } \\
\text { household incomes }\end{array}$ & Used Stability Index & 3 \\
\hline Index 4 & $\begin{array}{l}\text { The rate of increase in } \\
\text { agricultural production }\end{array}$ & $\begin{array}{l}\text { Rate of increase in the } \\
\text { volume of agricultural } \\
\text { exports, the tone }\end{array}$ & Business Index & 4 \\
\hline Index 5 & $\begin{array}{l}\text { Rate of population increase in } \\
\text { rural }\end{array}$ & $\begin{array}{l}\text { - Rate of increase in } \\
\text { agricultural }\end{array}$ & Food Security & 5 \\
\hline
\end{tabular}


International Journal of Geography and Geology, 2014, 3(7): 86-100

\begin{tabular}{|c|c|c|c|c|}
\hline & & production & & \\
\hline Index 6 & Rate of inflation & $\begin{array}{l}\text { Rates of wages for } \\
\text { agricultural workers }\end{array}$ & Purchasing power & 6 \\
\hline Index 7 & $\begin{array}{l}\text { - The rate of increase in annual } \\
\text { income urban }\end{array}$ & $\begin{array}{l}\text { The rate of increase in } \\
\text { annual income for } \\
\text { rural }\end{array}$ & $\begin{array}{l}\text { Urban-rural income } \\
\text { gap }\end{array}$ & 7 \\
\hline Index 8 & Optimize the use of water & $\begin{array}{l}\text { Average rate of } \\
\text { rainfall }\end{array}$ & Water resources & 8 \\
\hline Index9 & The total agricultural land & $\begin{array}{l}\text { The rate of increase of } \\
\text { new irrigated lands }\end{array}$ & Mechanization & 9 \\
\hline Index 10 & The total production area & $\begin{array}{l}\text { Rates increased } \\
\text { product sales to } \\
\text { government } \\
\text { (guaranteed) }\end{array}$ & $\begin{array}{l}\text { The marketing (selling } \\
\text { products) }\end{array}$ & 10 \\
\hline Index 11 & The total land & $\begin{array}{l}\text { Increase the rate of } \\
\text { insurance for } \\
\text { agricultural land }\end{array}$ & $\begin{array}{l}\text { Yes, the } \\
\text { operating risks }\end{array}$ & 11 \\
\hline Index 12 & $\begin{array}{l}\text { The rate of increase of rural } \\
\text { income }\end{array}$ & $\begin{array}{l}\text { Rate of increase in } \\
\text { agricultural income }\end{array}$ & $\begin{array}{l}\text { Sustainability } \\
\text { agricultural income }\end{array}$ & 12 \\
\hline
\end{tabular}

Source: Survey Results

To calculate the degree of stability $(\mathrm{SD}=\mathrm{SD})$, based on indicators should be introduced, "the status quo (S)," and "the driving force (D)", should be evaluated. (Fritz and Francesco, 2003). For this purpose, the reaction rate was compared against threats rates, and the instability is determined (Simon and Stephen, 2003) convention, the degree of stability is rated from 0 to 100 , where zero, indicating a complete lack of stability, and a 100 degree full stability, is considered. Table (5), the results of calculations to assess the sustainability of rural development, with emphasis on agricultural activities in the period 2011-2002 shows.

Sustainability indicators used to measure

\begin{tabular}{lll}
\hline Index Commentary & Index cost & degree \\
\hline Very stable & $100-80$ & 1 \\
\hline Stable & $80-60$ & 2 \\
\hline Moderate persistent & $60-40$ & 3 \\
\hline Weak sustainability & $40-20$ & 4 \\
\hline Unstable (bad) & $20-0$ & 5 \\
\hline
\end{tabular}

(Fritz and Francesco, 2003) Source:

The results of calculations of stability testing for agricultural activities in the period 20112002 shows that, with the growing inflation in the period under review, and production costs, and the lack of a proportionate increase in product prices and low rates The government guarantees the purchase price, low rate of increase in agricultural wages relative to inflation, limited use of mechanization in harvesting, and modern irrigation and farmers' lack of interest, insurance, own land, the main reason for the instability of rural development due to agricultural activities 's. On the other hand, increased government aid to the villagers, in the form of non-farm incomes, and banking facilities, good food security due to mass production, and increase the sustainability of 
agriculture, is. The analysis used data also show that, despite an increase in product exports during the period under review, exports of high volatility are insufficient.

Table-5. The results of calculations to assess the sustainability of rural development, with emphasis on agricultural activities in the period 2011-2002

\begin{tabular}{|c|c|c|c|c|}
\hline Economic reasons & STABLE & $\begin{array}{l}\text { The index } \\
\text { value }\end{array}$ & $\begin{array}{l}\text { Symbol } \\
\text { index }\end{array}$ & Index \\
\hline $\begin{array}{l}\text { The low percentage price increases, the } \\
\text { cost of production }\end{array}$ & Low stability & 35 & Index 1 & Profitability Index \\
\hline Guaranteed not to raise prices, inflation & Unstable & 15 & Imdex 2 & $\begin{array}{l}\text { Index supportive } \\
\text { government policies }\end{array}$ \\
\hline Due to the increase in non-farm income & Stable & 75 & Index3 & Used Stability Index \\
\hline $\begin{array}{l}\text { Given a constant rate of production, and } \\
\text { the lowest rate of export }\end{array}$ & $\begin{array}{l}\text { Moderate } \\
\text { persistent }\end{array}$ & 55 & Index 4 & Business Index \\
\hline $\begin{array}{l}\text { According to the mass-produced product } \\
\text { in the region (except for economic access) }\end{array}$ & Stable & 80 & Index 5 & $\begin{array}{l}\text { Food security (production } \\
\text { and consumption of } \\
\text { agricultural products in } \\
\text { Kermanshah) }\end{array}$ \\
\hline Higher inflation, wage & Low stability & 30 & Index 6 & Purchasing power \\
\hline $\begin{array}{l}\text { According to official figures, annual } \\
\text { household incomes in rural and urban }\end{array}$ & Stable & 65 & Index 7 & Urban-rural income gap \\
\hline province suitable Precipitation & $\begin{array}{l}\text { Moderate } \\
\text { persistent }\end{array}$ & 50 & Index 8 & Water Resources \\
\hline $\begin{array}{l}\text { Minimal use of machinery and new } \\
\text { farming systems, and widespread flood } \\
\text { irrigation }\end{array}$ & Low stability & 25 & Index9 & Mechanization \\
\hline Low rate guaranteed purchase & Stable & 80 & Index 10 & $\begin{array}{l}\text { The marketing (selling } \\
\text { products) }\end{array}$ \\
\hline Percent of insured & Low stability & 30 & Index 11 & Risk agricultural activities \\
\hline $\begin{array}{l}\text { According to official statistics, the annual } \\
\text { income of rural households }\end{array}$ & Stable & 65 & Index 12 & $\begin{array}{ll}\text { Agricultural } & \text { Income } \\
\text { Stabilization } & \end{array}$ \\
\hline
\end{tabular}

Source: Calculations research

The export price though compared to the year earlier period, has risen, in any case, given the government's liberalization policies, and targeted subsidies, the elimination of water and fertilizer (due to high consumption of water, agricultural activities), and other factors of production, the economic sustainability of agricultural activities, will change drastically.

\section{CONCLUSIONS AND RECOMMENDATIONS}

The purpose of this study was to assess the sustainability of rural development, Kermanshah district (Kermanshah Province), with emphasis on the economic aspects of agriculture, which, for this purpose was introduced more than 25 indicators, which according to the data available, the 12 Index, a method for calculating DSR (response - status quo - reaction), were considered. The results of the model used, the indicators used, show that stability, rural development, agricultural activities down to reliance has been, and continues to the present situation can not be sustainable development for rural areas, is surveyed. One of the main reasons for this instability, the increasing cost of agricultural production, on the one hand, and the low prices of the other party, that is, the value added of this sector was low and income from agricultural activities ( 28 percent of total rural income), not sustainable rural development, to be held. Therefore, to optimize production costs through efficiency (lower cost pricing of water, prevent waste), the promotion of 
organic farming, promotion of high-yielding varieties and commercial development on foreign markets, to create demand for the product and packaging improvements product packaging, to increase added value, to a large extent can, to strengthen the region's agriculture and sustainable rural development to the region.

\section{Notes}

[1] Ec.europa.eu / agriculture / index_en.htm

[2] (CSD: Commission on Sustainable Development)

[3] (DSR: Driving Force-State-Response)

Funding: This study received no specific financial support.

Competing Interests: The authors declare that they have no competing interests.

Contributors/Acknowledgement: All authors contributed equally to the conception and design of the study.

\section{REFERENCES}

Amani Kelarijani, A., 2001. Resources and rural development issues, with emphasis on agriculture and ranching, rural Lefebvre, Mount literate city. Thesis (MS) - University of Shahid Beheshti.

Ayoobi, S., 1995. Rural development, agricultural axis (Sample Nimbolok Plain Qaen). Thesis (MS) University of Mashhad, Faculty of Literature and Humanities, Dr. Ali Shariati, 1994-1995. County Planning Department, Kermanshah Province Statistical Yearbook, Various Years Customs Kermanshah, Statistic Exporting State, Various Years.

Connelly, J. and G. Smith, 1999. Politics and the environment, from theory to practice. London \& New York. WB, 2005: Routledge. Available from http://web.worldbank.org/WBSITE/EXTERNAL/TOPICS/EXTARD/O,,contentMDK:204390 77 menuPK:336688 pagePK:148956 piPK:216618 theSitePK:336682,00.html.

Eric, L. and M. Navarrete, 2009. Sustainable agriculture. London: Springer Dordrecht Heidelberg. ISBN.978-90-48 1-2665-1.

Fritz, H. and B. Francesco, 2003. RISE, a tools for holistic sustainability assessment at the farm level. International Food and Agribusiness Management Review, 6(4): 78-90.

Gray, R., 1991. Economic measure of sustainability. Canadian Journal of Agriculture Economics, 39(4): 627635.

Hedayatian, M., 1995. District rural development strategy Zeberkhan Neishaboor, with emphasis on the agricultural sector. Thesis (MS) - University of Mashhad, Faculty of Literature and Humanities, Dr. Ali Shariati.

Naderi Mahdi, K., 2002. Evaluation of sustainable development of ecological agriculture in Saleh Abad. Thesis (MA) - Faculty of Agriculture, Tehran University. Department of Agricultural Extension and Education.

Naturland, E.V., 2002. Organic farming in the tropics and subtropics exemplary description of 20 crops date palm: Germany, 82166 Gräfelfing. Available from www.naturland.de. 
OECD, 2001. The DAC guidelines, strategies for sustainable development. Planning Statuary, Kermanshah Province Economic Report, Various Years.

Shaheed Hossain, M., 2009. Traditional utilization of wild date palm (Phoenix Sylvestris Roxb) in rural Bangladesh: An approach to sustainable biodiversity management forest policy laboratory, Department of Forest Science, Faculty of Agriculture, Shinshu University, 8304 MinamiminowaMura, 399-4598 Nagano-Ken, Japan.

Simon, B. and Stephen, 2003. Measuring sustainability: Learning by doing. London; Sterling, VA: Earthscan Publications Ltd.

Soleimani, H., 1998. Rural development, agricultural villages around the city anymore Khrqan. Thesis (MS)

- University of Mashhad, Faculty of Literature and Humanities, Dr. Ali Shariati.

Statistical Center of Iran, 2006. The country's total population and housing census.

Statistical Center of Iran, 2008. The summary results of census of the country Baghdaryhay.

WCED, 1987. Our common future. Oxford: Oxford University Press.

Weingarten Peter Petrick, M., 2004. The role of agriculture in central and Eastern European rural development: Engine of change or social buffer? Studies on the Agricultural and Food Sector in Central and Eastern Europe, 25. Available from http://purl.umn.edu/14946.

\section{BIBLIOGRAPHY}

Mohd Azhari, B.G., 2006. Sustainable development agricultural sector in Malaysia, Department of Irrigation and Drainage Malaysia, 50626 Kuala Lumpur. 